\title{
Molecular Genetic DiversityAmong 12 Clones of Lagerstroemia fauriei Revealed by AFLP and RAPD Markers
}

\author{
Margaret R. Pooler
}

U.S. Dept. of Agriculture, Agricultural Research Service, U.S. National Arboretum, 3501 New York Avenue, NE, Washington, DC 20002

Additional index words. crapemyrtle, DNA fingerprinting, germplasm

\begin{abstract}
Many popular crapemyrtle (Lagerstroemia L.) cultivars grown in the United States are interspecific hybrids between $L$. indica $L$. and $L$. fauriei Koehne. The 22 hybrid cultivars released from the U.S. National Arboretum contain primarily genetic material from $L$. fauriei PI 237884. Examining the genetic diversity of $L$. fauriei specimens in the U.S. is valuable because of the historical and economic significance of the species, the increasing interest it is receiving as a source of new cultivars, and its threatened status in the wild. Our objectives were to examine molecular genetic diversity among $L$. fauriei accessions using Randomly Amplified Polymorphic DNA (RAPD) and Amplified Fragment Length Polymorphisms (AFLP) markers. Our results indicate: 1) RAPD and AFLP markers are generally consistent in the genetic relationships that they suggest; 2 ) the $L$. fauriei germplasm we examined falls into at least three distinct clusters; and 3) the genetic base of cultivated Lagerstroemia could be broadened significantly by incorporating some of this more diverse $L$. fauriei germplasm into breeding programs.
\end{abstract}

The crapemyrtle is a popular shrub or tree with hundreds of named cultivars that offer the grower diverse combinations of flower color, growth habit, and bark characteristics (Egolf and Andrick, 1978). Although originally imported from Asia, the crapemyrtle or "lilac of the south" has become a mainstay in gardens of the southern United States, and represents a significant source of income for both wholesale and retail nursery growers. The popularity of crapemyrtle is evidenced by the recent establishment of the Crapemyrtle Society of America (http://www. thecrapemyrtlesocietyofamerica.org).

Until the early 1970s, most crapemyrtles grown in the United States were cultivars of L. indica. Although this species has ample diversity in terms of size, flower color, and habit, it tends to be susceptible to powdery mildew (Erysiphe lagerstroemiae $\mathrm{E}$. West.). In 1967 and 1970, six disease-tolerant $L$. indica cultivars ('Catawba', 'Cherokee', 'Conestoga', 'Potomac', 'Powhatan', and 'Seminole') were introduced from the breeding program at the U.S. National Arboretum (Egolf, 1967, 1970). These cultivars were improvements over previous cultivars, but were not sufficiently mildew resistant for humid southern climates.

In 1956, John Creech collected seeds of $L$. fauriei from Japan. These seeds were introduced and distributed throughout the United States by the U.S. Dept. of Agriculture (USDA) as PI 237884 (Creech, 1985). This rare and

Received for publication 12 Dec. 2001. Accepted for publication 8 May 2002. Mention of a trademark, proprietary product, or vendor does not constitute a guarantee or warranty of the product by the U.S. Dept. of Agriculture and does not imply an endorsement of these products over others not mentioned. I wish to thank L. Riedel and S. Johri for skilled technical assistance in performing RAPD analysis. possibly threatened species is reportedly found only on the island of Yakushima, Japan (Creech, 1985; Ohwi, 1965). Although similar in hardiness to $L$. indica, L. fauriei is a larger plant, has exceptional ornamental bark, and tolerates powdery mildew (Egolf and Andrick, 1978). The first named interspecific hybrid cultivar between the two species was 'Basham's Party Pink', a chance seedling discovered in Texas and introduced in 1965. Hybridizations made at the National Arboretum in 1964 between L. indica and L. fauriei resulted in the 1978 introduction of the mildew-resistant cultivars 'Natchez' and 'Muskogee', the first intentional crosses using L. fauriei (Egolf, 1981a). Since then, 20 additional $L$. indica (L.fauriei hybrids have been released by the U.S. National Ar- boretum (Egolf, 1981b, 1986a, 1986b, 1987a, 1987b, 1990a, 1990b; Pooler and Dix, 1999). Many of these ornamental and disease-resistant cultivars have become standards in the nursery and landscape industries (Byers, 1997). Several cultivars of pure L. fauriei, including 'Kiowa', 'Fantasy', and 'Townhouse', have also been released in the past two decades by the U.S. National Arboretum ('Kiowa') and the Raulston Arboretum in Raleigh, N.C. (Byers, 1997; Pooler and Dix, 1999).

An examination of the genetic diversity of L. fauriei accessions in the United States is valuable because of the historical and economic significance of the species, the increasing interest it is receiving as pure species cultivars, and its threatened status in the wild. This information could be used to broaden the genetic base of cultivated Lagerstroemia by using different sources of $L$. fauriei in interspecific hybridization. In addition, DNA fingerprinting can be useful in germplasm management and in answering questions about plant identity. There is interest in determining whether a group of $L$. fauriei cuttings received by the U.S. National Arboretum in 1968 is clonal. The objectives of this study were to: 1) examine the genetic diversity among 12 clones of $L$. fauriei plus the interspecific hybrid 'Natchez' using both RAPD and AFLP markers; 2) compare the results of the two methods; and 3) determine the genetic status of the group of plants received at the National Arboretum in 1968.

\section{Materials and Methods}

DNA extraction. Newly expanding leaves were collected in the spring and freeze-dried (Table 1). For each sample, four leaves were placed in a lysing matrix (Bio101, Vista, Calif.) with $500 \mu \mathrm{L}$ CTAB buffer and processed in a FastPrep FP120 machine (Bio101) on speed 4 for $12 \mathrm{~s}$. The resulting homogenate was incubated at $65^{\circ} \mathrm{C}$ for $15 \mathrm{~min}$ then extracted with $500 \mu \mathrm{L}$ of a 24 chloroform : 1 isoamyl alcohol mix (by volume). The DNA from this crude

Table 1. Crapemyrtle accession information for 12 L. fauriei samples and the interspecific hybrid 'Natchez'.

\begin{tabular}{|c|c|c|c|}
\hline $\begin{array}{l}\text { Accession } \\
\text { name }\end{array}$ & $\begin{array}{c}\text { PI } \\
\text { number }\end{array}$ & $\begin{array}{l}\text { Collection } \\
\text { information }\end{array}$ & $\begin{array}{l}\text { Date received } \\
\text { at U.S. National } \\
\text { Arboretum }\end{array}$ \\
\hline 34 & 237884 & $\begin{array}{l}\text { J. Creech. Collected } 1956 \text { as seed in mountain. forest } \\
\text { above Kurio, Yakushima. Elevation } 350 \text { m (3 plants recd. } \\
\text { through Glenn Dale, Md. Plant Introduction station) }\end{array}$ & 1959 \\
\hline $617,617-94$ & 326424 & $\begin{array}{l}\text { Y. Tachibana, Osaka, Japan. Collected near Onoma, } \\
\text { Yakushima Island. Elevation } \approx 100 \text { m ( } 9 \text { cuttings received })\end{array}$ & 1968 \\
\hline Bonsai & & 617 & 1968 \\
\hline Kiowa & 583789 & 617 & 1968 \\
\hline 732 & & $\begin{array}{l}\text { Creech and March. Collected as cuttings } 11 / 76 \text { from tree } \\
\text { with red brown bark along logging road above Ambo, } \\
\text { Yakushima, Elevation } \approx 400 \mathrm{~m} \text {. (one plant received). }\end{array}$ & 1977 \\
\hline 766 & & $\begin{array}{l}\text { B. Yinger. Collected as seed } 4 / 77 \text {. Growing } 15 \mathrm{mi} \text {. west of } \\
\text { Ambo, Yakushima in a garden. Elevation } \approx 30 \mathrm{~m} \text {. }\end{array}$ & 1982 \\
\hline $772-74,772-75$ & & $\begin{array}{l}\text { B. Yinger. Collected as cuttings } 1 / 78 \text { in the wild from a stream } \\
\text { bank at bottom of deep ravine, Kumage-Gun, Senpiro-Dake } \\
\text { Elevation } \approx 200 \mathrm{~m} \text { ( } 3 \text { plants received via Brookside Gardens). }\end{array}$ & 1984 \\
\hline Fantasy & 237884 & Received through Raulston Arboretum, Raleigh, N.C. & 1998 \\
\hline Townhouse & & $\begin{array}{l}\text { Seedling of 'Fantasy' (received through Raulston Arboretum, } \\
\text { Raleigh, N.C.). }\end{array}$ & 1998 \\
\hline NCSU & 237884 & Received through Raulston Arboretum, Raleigh, N.C. & 1998 \\
\hline Natchez & 427115 & L. indica 'Pink Lace x L. fauriei 34. Released 1978. & $\begin{array}{l}\text { Hybridized } \\
1964\end{array}$ \\
\hline
\end{tabular}


extract was then isolated by using a QIAamp Tissue Kit (Qiagen, Valencia, Calif.). DNA purity and quantity were estimated by visual comparison with known standards on a $1 \%$ agarose gel.

$R A P D-P C R$. PCR was performed in $25-\mu \mathrm{L}$ volumes containing PCR buffer $(20 \mathrm{~mm} \mathrm{NaCl}$, $50 \mathrm{~mm}$ Tris $\mathrm{pH}$ 9.0, $1 \%$ Triton $\mathrm{X}-100$ [Barry et al., 1991]), $3 \mathrm{~mm} \mathrm{MgCl}, 200 \mu \mathrm{M}$ dNTP, $0.2 \mu \mathrm{M}$ primer (primers with $70 \%$ to $90 \% \mathrm{G}+\mathrm{C}$ content were selected from UBC sets 1 and 4; UBC Nucleic Acid-Protein Service Unit, Vancouver, B.C., Canada), 0.25 U of Taq DNA polymerase (Promega Corp., Madison, Wis.), and $10 \mathrm{ng}$ DNA template. DNAamplification was carried out in a GeneAmp PCR System 2400 (Perkin-Elmer, Norwalk, Conn.) programmed for 45 cycles of $30 \mathrm{~s}$ at $95^{\circ} \mathrm{C} ; 30 \mathrm{~s}$ at $48^{\circ} \mathrm{C}$, and $45 \mathrm{~s}$ at $72^{\circ} \mathrm{C}$. RAPD reactions were analyzed on $1.4 \%$ agarose TBE gels stained with ethidium bromide. Gels were visualized and documented using an AlphaImager 2000 (Alpha Innotech Corp., Alameda, Calif.). All reactions were repeated at least once to ensure reproducibility of scored amplification products. Polymorphic RAPD-PCR amplification products were listed as discrete character states per accession (presence or absence of band).

AFLP reactions. Amplified Fragment Length Polymorphism (AFLP) electropherograms were generated for accessions using protocols described by Vos et al. (1995) and Perkin-Elmer Corp. (1996), with slight modifications, to prepare samples for analysis on an ABI310 Genetic Analyzer(PEApplied Biosystems, Foster City, Calif.). DNA restriction and ligation were carried out sequentially instead of simultaneously, using $\approx 0.25 \mu \mathrm{g}$ of genomic DNA. Restriction was carried out at $37^{\circ} \mathrm{C}$ for $2 \mathrm{~h}$, and ligations were carried out at $20^{\circ} \mathrm{C}$ for $2 \mathrm{~h}$. Preselective reactions were carried out in $20 \mu \mathrm{L}$ volumes containing the buffer described above for RAPDs, plus $3 \mathrm{~mm} \mathrm{MgCl}, 100 \mu \mathrm{M}$ dNTP, $0.125 \mu \mathrm{M}$ each preselective primer, $0.625 \mathrm{U}$ of Taq DNA polymerase, and $4 \mu \mathrm{L}$ diluted restriction/ligation reaction. Completed preselective reactions were diluted with $380 \mu \mathrm{L}$ molecular grade water and $3 \mu \mathrm{L}$ were used as template for all selective reactions. Selective amplification reactions were carried out in $20-\mu \mathrm{L}$ volumes containing the same reagents as for preselective amplification except that $0.25 \mu \mathrm{M} \mathrm{MseI} \mathrm{primer} \mathrm{and} 0.1 \mu \mathrm{M} \mathrm{EcoRI} \mathrm{prim-}$ ers were used instead of preselective primers. The EcoRI selective primers had fluorescently labeled 5' ends and were purchased from the Applied Biosystems Custom Oligonucleotide Synthesis Service (Foster City, Calif). Completed selective reactions were analyzed on an ABI310 with POP4 polymer. The sample was prepared by mixing $1 \mu \mathrm{L}$ of selective reaction, $0.3 \mu \mathrm{L}$ ROX size standard, and $9.7 \mu \mathrm{L}$ deionized formamide. Markers were scored with Genotyper 2.5 software (Applied Biosystems). All reactions were repeated from the DNA extraction through the selective reactions to ensure reproducibility of results.

Data analysis. Similarity coefficients between each accession were calculated using the SIMQUAL program in NTSYS-pc, version 1.70 (Rohlf, 1992), using the Dice similarity coefficient $[2 \mathrm{a} /(2 \mathrm{a}+\mathrm{b}+\mathrm{c})$, where $\mathrm{a}=$ total number of bands shared by both individuals, $\mathrm{b}=$ bands unique to one individual, and $\mathrm{c}=$ bands unique to the other individual]. These data were subjected to cluster analysis using the UPGMA, single-link, and complete-link methods in the SAHN program of NTSYS to generate a phenogram. Cophenetic matrices were constructed and compared with the similarity matrices using the MXCOMP program to test the goodness of fit of a cluster. Bootstrap analysis using 5000 replications was performed using WinBoot (Yap and Nelson, 1996) to determine confidence limits of clusters in the UPGMA-based dendrograms. The bootstrap value indicates the percentage of times the group to the right of the node occurred in the bootstrap analysis.

\section{Results}

The analysis of RAPD markers to assess the diversity of 12 clones of $L$. fauriei and the interspecific hybrid 'Natchez' resulted in a UPGMA-based phenogram with a cophenetic correlation coefficient ( $r$ ) of 0.92 (Fig. 1). The phenograms resulting from the single-link and the complete-link methods were slightly different than the UPGMA-derived phenogram. The UPGMA clustering results are presented for all analyses because this method yielded the highest cophenetic correlation coefficient for each data set. The complete-link method consistently yielded the lowest cophenetic correlation coefficient. Bootstrap confidence values for the consensus tree based on RAPD data ranged from $31.3 \%$ to $99.7 \%$, indicating that some clusters are not robust and may be an artifact of the clustering technique rather than a reflection of the true genetic relationships among accessions. The RAPD-derived phenogram (Fig. 1) is based on 43 polymorphic markers from 20 primers. Originally, 30 primers were tested, which resulted in 99 scorable bands; problems in reproducibility reduced this number to 81 markers from 26 primers. Of these 81 markers, 38 were monomorphic.

Analysis of AFLP markers resulted in significantly more markers per primer and revealed a second UPGMA phenogram (Fig. $2)$. The correlation coefficient $(r)$ for this phenogram was 0.95 . The bootstrap confidence values for the consensus tree of this data set ranged from $60.5 \%$ to $100 \%$, thus indicating more robust clusters than the RAPD data set. This phenogram is based on 88 markers from 10 primer combinations. Originally, 446 markers were scored by Genotyper as polymorphic; however, many of these markers were actually present in all individuals, but not called by the software due to low peak height. Additional markers were omitted from the analysis because they were very small $(<80 \mathrm{bp})$, they were difficult to read due to proximity to another marker, or they were not present in both replicates. Generally, the most useful markers were $100-275$ bp in size.

AUPGMA-derived phenogram based on a balanced combination of the RAPD and AFLP data sets was generated using all 43 RAPD markers and 43 randomly chosen AFLP markers (Fig. 3). The clusters and similarity values of the combined data phenogram changed slightly depending on which of the 43 out of 88 AFLP markers were included. The cophenetic correlation coefficient $(r)$ for this phenogram was 0.94 , and bootstrap confidence values for the consensus tree ranged from $49.3 \%$ to $100 \%$.

Comparing the two methods, RAPD analysis yielded an average of 3.1 scorable bands per primer, with 2.2 polymorphic bands per primer. This low average number of bands per primer compared to other labs (e.g., Welsh and McClelland, 1990) can be explained by the higher stringency $\left(48^{\circ} \mathrm{C}\right.$ vs. $\left.36^{\circ} \mathrm{C}\right)$ annealing temperature used in the present study. Analysis of AFLP data yielded $\approx 40$ reliable bands per primer, with 9.5 polymorphic bands per primer.
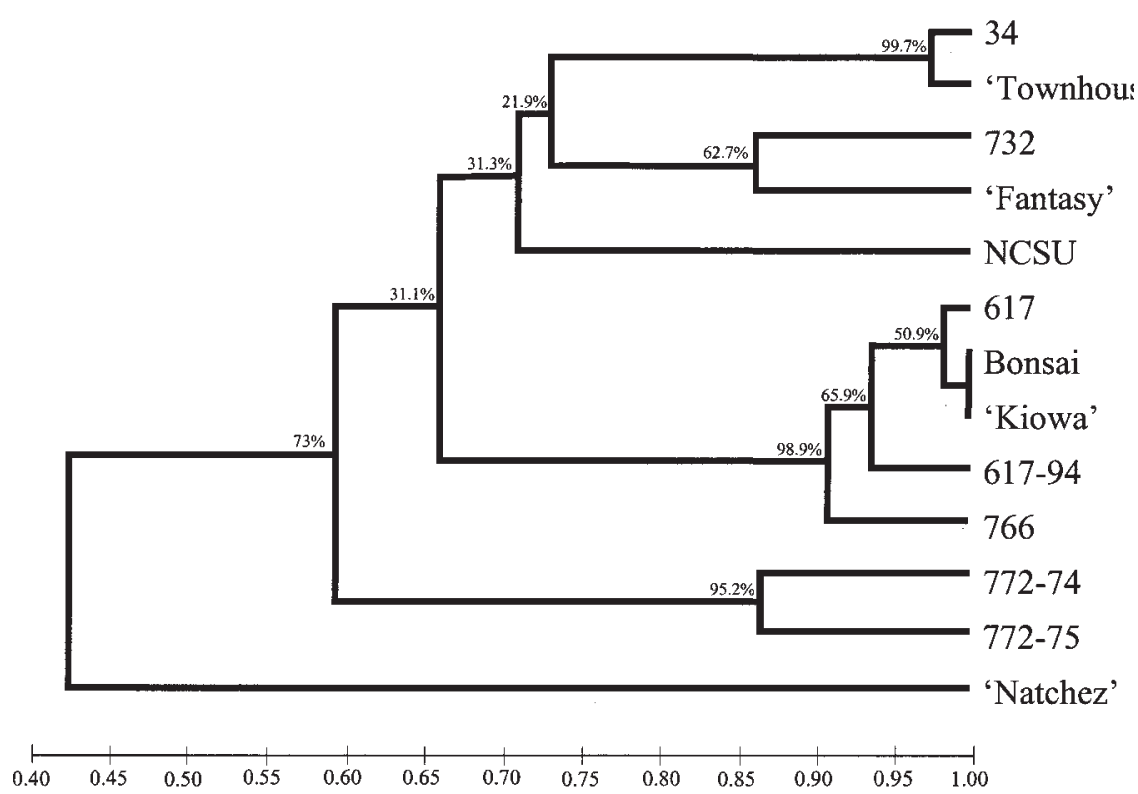

Fig. 1. UPGMA-derived phenogram of genetic similarity of $L$. fauriei accessions and 'Natchez' based on 43 characters from 20 RAPD primers. Cophenetic correlation coefficient $(r)=0.92$. Bootstrap confidence values for clusters are indicated on the left of each node. 


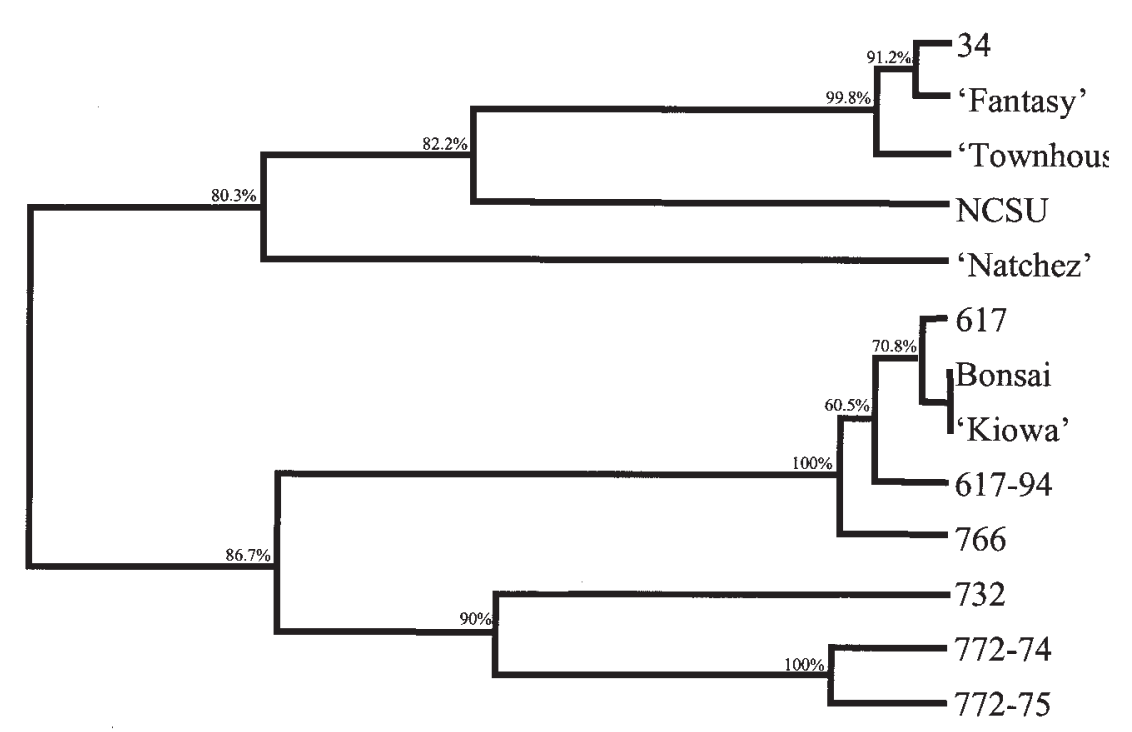

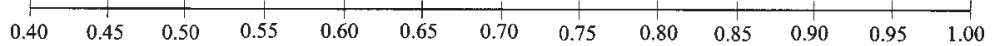

Fig. 2. UPGMA-derived phenogram of genetic similarity of L. fauriei accessions and 'Natchez' based on 88 characters from 10 AFLP primer pairs. Cophenetic correlation coefficient $(r)=0.95$. Bootstrap confidence values for clusters are indicated on the left of each node.

Despite the high cost of restriction and ligation enzymes, size standards, and capillaries necessary for automated AFLP analysis, the costs of AFLP and RAPD analysis were similar when comparing the amount of useful information (polymorphic bands) per run.

\section{Discussion}

Although AFLP and other DNA fingerprinting technologies are becoming increasingly common, RAPD markers are still used by many labs, so a comparison of these two methods is valuable. Part of the differences in reproducibility and number of markers per primer between the two methods can be attributed to the method used to detect bands. The increase in sensitivity and objectivity of assessing fluorescently labeled markers on an automated machine may account in part for the larger number of useful markers per primer with AFLPs.

The phenograms generated by the RAPD and AFLP data have a significant discrepancy in the placement of clones 732 and 'Natchez', as well as the bootstrap confidence values of many clusters. Comparative marker studies in soybean [Glycine max (L.) Merrill] (Powell et al., 1996), gooseberry (Ribes grossularia subgenus Grossularia) (Lanham and Brennan, 1999), pear (Pyrus communnis L.) (MonteCorvo et al., 2000) and plum (Prunus domestica) (Goulão et al., 2001) also revealed different phenograms from different marker sets. Although both methods sample randomly from the genome, different results can originate from differences in the tolerance of primer-template mismatches between the two methods, linkage disequalibria between closely related samples, and scoring errors. Based on the higher bootstrap confidence values of the clusters, the phenogram based on AFLP markers is probably more accurate than that based on RAPDs. This difference in cluster robustness is solved at the 0.70 similarity level, which can be correlated to recorded collection information. The AFLP phenogram (Fig. 2) resolves these three clusters at close to $100 \%$ bootstrap confidence values. The first cluster contains clone 34 (PI 237884), 'Fantasy', 'Townhouse', and more distantly, NCSU, each of which were seedlings or derived from seedlings grown from the original 1956 collection trip to Yakushima by John Creech, and distributed in 1959 to various arboreta and botanic gardens around the country. Clone 34 was a parent in the interspecific hybridization with $L$. indica to produce 'Natchez' and many other hybrids developed at the U.S. National Arboretum. 'Fantasy' was grown at the Raulston Arboretum at NCSU and named in 1982 (Byers, 1997). 'Townhouse', a seedling selection from 'Fantasy' released in 1986 (Byers, 1997), is most likely a self-pollinated seedling or resulted from a cross with another tree from the PI 237884 distribution, based on its close relationship to others in this group. The plant labeled "NCSU" was sent to the National Arboretum with 'Fantasy' and 'Townhouse' from the Raulston Arboretum, and is also thought to be a seedling from the PI 237884 distribution. The genetic distance between the NCSU accession and the others indicate that the original mountain population from which Creech collected seed in 1956 was diverse.

The next cluster of L. fauriei, the 'Kiowa' group, consists primarily of plants that were sent as cuttings to the National Arboretum in 1968 from Y. Tachibana in Osaka, Japan. Accession records were unclear whether these cuttings were from a single tree or multiple trees. There was particular interest in determining whether the plant that was selected and released in 1994 as 'Kiowa' (Pooler and Dix, 1999) was identical to a plant growing near the entrance of the Bonsai courtyard at the National Arboretum. From these studies, the cuttings received in 1968 were not taken from a single plant, although the Bonsai plant and 'Kiowa' could be clonal. The accession 766 was collected as seed in a garden in Yakushima three clusters of $L$. fauriei accessions can be re-
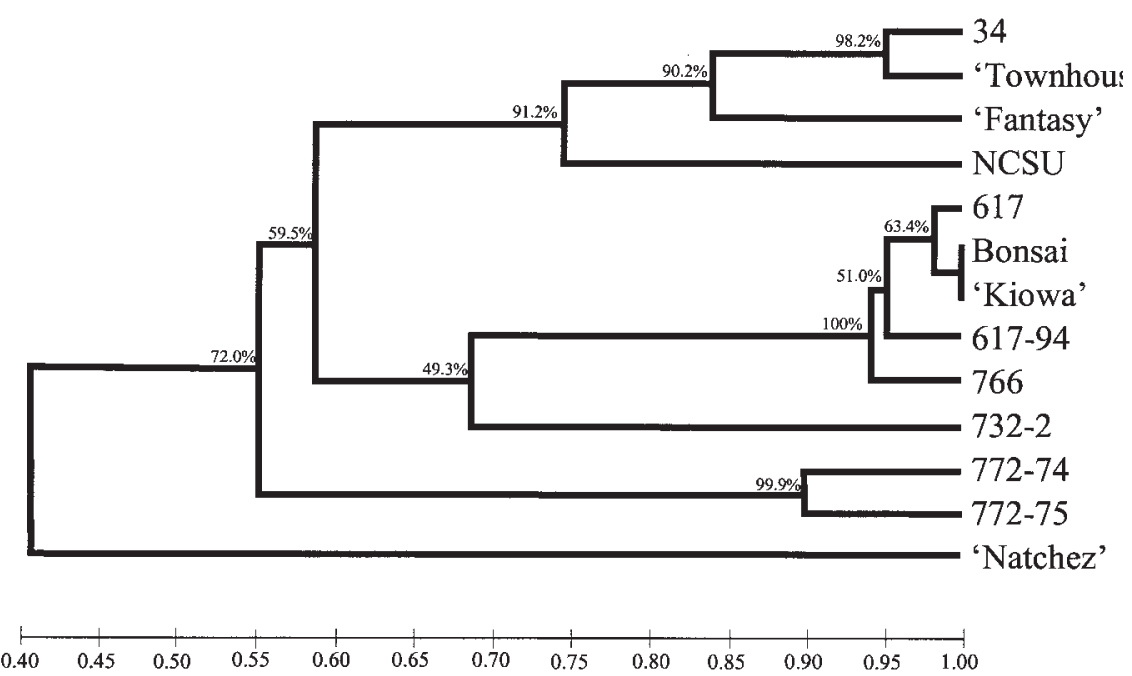

Fig. 3. UPGMA-derived phenogram of genetic similarity of $L$. fauriei accessions and 'Natchez' based on 86 characters from RAPD and AFLP data sets. Cophenetic correlation coefficient $(r)=0.94$. Bootstrap confidence values for clusters are indicated on the left of each node. 
in 1977, and based on our analysis, could be from a tree from which Y. Tachibana sent cuttings in 1968.

The clones identified as 772 in the third cluster were originally collected as vegetative material by B. Yinger in 1978 from plants growing in the wild on a stream bank at the bottom of a ravine in Yakushima. Plant 732, which clusters either in the 772 group (AFLP, 90\% bootstrap confidence value) or the 34 group (RAPD, $62.7 \%$ bootstrap confidence value) was collected as a cutting from a single plant in 1976 in Yakushima by Creech and March. The clustering of 'Natchez' also varied depending on DNA fingerprinting method. Although 'Natchez' had many unique markers due to the presence of L. indica in its background, its placement close to the PI 237884 group by AFLP analysis simply reflects the fact that it is more closely related to this group than it is to the other L. fauriei accessions.

Knowledge of genetic diversity is a key concept in the maintenance and utilization of plant germplasm. Relying solely on accession data to derive plant origins to estimate diversity can be misleading due to the ease with which plant material historically has traveled globally. For example, one accession (766) collected in 1977 as seed from a plant growing in a garden 15 miles west of Ambo in Yakushima, was closely related to another accession (617) received in 1968 as cuttings from a botanist in Osaka. Using morphological features to assess genetic diversity can be effective for large populations with greater morphological diversity, but is not practical or informative for a species such as $L$. fauriei with so few representatives. In this study, molecular genetic diversity estimates supported known origin data, and helped elucidate relationships among plants with unknown or questionable origins.

Most of the 22 L. indica $\times$ L. fauriei hybrid cultivars released by the U.S. National Arboretum utilize either 34 as the L. fauriei donor, or 'Basham's Party Pink', an L. indica $x$ L. fauriei chance seedling that originated in 1963 in Texas (Egolf and Andrick, 1978).
The L. fauriei parent of 'Basham's Party Pink' was probably also from the original PI 237884 distribution from which 34 originated. Only 'Apalachee', released from the National Arboretum in 1987 (Egolf, 1987b), contains a separate source of L. fauriei germplasm, namely 617 . The information on the genetic relationships among accessions of $L$. fauriei provided by this study should be valuable in future breeding work to broaden the genetic base of cultivated Lagerstroemia.

\section{Literature Cited}

Barry, T., G. Colleran, M. Glennon, L.K. Dunican, and F. Gannon. 1991. The 16s/23s ribosomal spacer region as a target for DNA probes to identify eubacteria. PCR Methods Appl. 1: 51-56.

Byers, M.D., Jr. 1997. Crapemyrtle-A grower's thoughts. Owl Bay Publishers. Auburn, Ala.

Crapemyrtle Society of America web site http: //www.thecrapemyrtlesocietyofamerica.org. Accessed 19 Apr. 2002.

Creech, J.L. 1985. Asian natives for American landscapes - The National Arboretum does more than gather seeds. Amer. Nurseryman 161(2):81-82.

Egolf, D.R. 1967. Four new Lagerstroemia indica cultivars. Baileya 15:7-13

Egolf, D.R. 1970. 'Cherokee' and 'Seminole'Two new cultivars of Lagerstroemia indica. Baileya 17:1-5.

Egolf, D.R. 1981a. 'Muskogee' and 'Natchez' Lagerstroemia. HortScience 16:576.

Egolf, D.R. 1981b. 'Tuscarora' Lagerstroemia. HortScience 16:788-789.

Egolf, D.R. 1986a. 'Tuskegee' Lagerstroemia. HortScience 21:1078-1080.

Egolf, D.R. 1986b. 'Acoma', 'Hopi', 'Pecos', and 'Zuni' Lagerstroemia. HortScience 21: 1250-1252.

Egolf,D.R. 1987a. 'Biloxi', 'Miami', and 'Wichita' Lagerstroemia. HortScience 22:336-338.

Egolf, D.R. 1987b. 'Apalachee', 'Comanche', 'Lipan', 'Osage', 'Sioux', and 'Yuma' Lagerstroemia. HortScience 22:674-677.

Egolf, D.R. 1990a. 'Caddo' and 'Tonto' Lagerstroemia. HortScience 25:585-587.

Egolf, D.R. 1990b. 'Choctaw' Lagerstroemia. HortScience 25:992-993.

Egolf, D.R. and A.O. Andrick. 1978. The La- gerstroemia handbook/checklist. Amer. Assn. of Botanical Gardens and Arboreta, Philadelphia.

Goulão, L., L. Monte-Corvo, and C. M. Oliveira. 2001. Phenetic characterization of plum cultivars by high multiplex ratio markers: amplified fragment length polymorphisms and inter-simple sequence repeats. J. Amer. Soc. Hort. Sci. 126:72-77.

Lanham, P.G. and R.M. Brennan. 1999. Genetic characterization of gooseberry (Ribes grossularia subgenus Grossularia) germplasm using RAPD, ISSR and AFLP markers. J. Hort. Sci. and Biotechnol. 74:361-366.

Monte-Corvo, L., L. Cabrita, C. Oliveira, and J. Leitão. 2000. Assessment of genetic relationships among Pyrus species and cultivars using AFLP and RAPD markers. Genetic Resources and Crop Evolution 47:257-265.

Ohwi, J. 1965. The flora of Japan. English translation. F.G. Meyer and E.H. Walker (eds.). Smithsonian Inst., Washington, D.C.

PE Applied Biosystems. 1996. In: AFLP plant mapping protocol. Revision B. The PerkinElmer Corp., Foster City, Calif.

Pooler, M.R. and R. Dix. 1999. 'Chickasaw', 'Kiowa', and 'Pocomoke' Lagerstroemia. HortScience 34:361-363.

Powell, W., M. Morgante, C. Andre, M. Hanafey, J. Vogel, S. Tingey, and A. Rafalski. 1996. The comparison of RFLP, RAPD, AFLP, and SSR (microsatellite) markers for germplasm analysis. Mol. Breeding 2:225-238.

Rohlf, F.J. 1992. NTSYS-pc. Numerical taxonomy and multivariate analysis system, version 1.70 . Exeter Publishing, Setauket, N.Y.

Vos, P., R. Hogers, M. Bleeker, M. Reijans, T. van de Lee, M. Hornes, A. Frijters, J. Pot, J. Peleman, M Kuiper, and M. Zabeau. 1995. AFLP: A new technique for DNA fingerprinting. Nucleic Acids Res. 23:4407-4414.

Waugh, R., N. Bonar, E. Baird, B. Thomas, A. Graner, P. Hayes, and W. Powell. 1997. Homology of AFLP products in three mapping populations of barley. Mol. Gen. Genet. 255:311-321.

Welsh, J. and M. McClelland. 1990. Fingerprinting genomes using PCR with arbitrary primers. Nucleic Acids Res. 18:7213-7218.

Yap, I.V. and R.J. Nelson. 1996. WinBoot: A program for performing bootstrap analysis of binary data to determine the confidence limits of UPGMA-based dendrograms. Intl. Rice Res. Inst., Manila, Philippines. 